Journal of Nutrition College, Volume 3, Nomor 1, Tahun 2014, Halaman 1 - 8

Online di : http://ejournal-s1.undip.ac.id/index.php/jnc

\title{
HUBUNGAN RIWAYAT PEMBERIAN ASI EKSKLUSIF DENGAN KEJADIAN OBESITAS PADA ANAK
}

\author{
Ermy Liesma Saputri, Ahmad Syauqy*) \\ Program Studi Ilmu Gizi Fakultas Kedokteran Universitas Diponegoro \\ Jl.Dr.Sutomo No.18, Semarang, Telp (024) 8453708, Email : gizifk@undip.ac.id
}

\begin{abstract}
Background : Obesity is one of health problems in the world. Obesity in children impact on the academic achievement and psychosocial effects such as lack of confidence. Obesity is influenced by food intake, physical activity, and the history of exclusive breastfeeding. Exclusive breastfeeding can prevent the obesity to children. The aim of this study is to know the correlation between history of exclusive breastfeeding and children obesity.

Method : The subject of this case control research is 28 obese children as the case subject and 28 non-obese children as the control at TK IT Bina Amal Semarang and TK Negeri Semarang. Obesity is determinate by Z-score value which is based on IMT/U. The history of exclusive breastfeeding obtained by interview. In addition, the energy input obtained by FFQ, while the physical activity obtained by recall form of physical activity.

Result : The history of exclusive breastfeeding has significant correlation with the obesity $(p=0.013: O R=4,2)$. The high intake of energy also has the risk factors that gaining obesity. $(p=0.032$ "OR=3,2). Otherwise, there is no correlation between physical activity and obesity $(p=0,589$ : $O R=1,3)$

Conclusion : The history of non-exclusive breastfeeding has 4, 2 times risk of children obesity, high energy intake has 3,2 times risk of children obesity, and low physical activity has 1,3 times risk of children obesity.

Keywords : exclusive breastfeeding, energy intake; physical activity; obesity
\end{abstract}

\begin{abstract}
ABSTRAK
Latar Belakang : Obesitas merupakan masalah kesehatan di seluruh dunia. Obesitas pada anak berdampak pada penurunan prestasi belajar dan dampak psikososial seperti kurang percaya diri. Obesitas dapat dipengaruhi oleh asupan makanan, aktivitas fisik dan riwayat pemberian ASI eksklusif. Riwayat pemberian ASI eksklusif dapat mencegah terjadinya obesitas pada anak. Tujuan dari penelitian ini adalah mengetahui hubungan antara riwayat pemberian ASI eksklusif dengan kejadian obesitas pada anak.

Metode : Subyek penelitian case control ini terdiri dari 28 anak dengan obesitas sebagai kasus, dan 28 anak yang tidak obesitas sebagai kontrol di TK IT Bina Amal Semarang dan TK Negeri Semarang. Penentuan obesitas dengan nilai Z-skor berdasarkan IMT/U. Data riwayat pemberian ASI eksklusif diperoleh melalui wawancara. Asupan energi diperoleh dengan wawancara menggunakan FFQ dan aktivitas fisik diperoleh dari formulir recall aktivitas fisik.

Hasil : Analisis bivariat menunjukkan bahwa riwayat pemberian ASI eksklusif mempunyai hubungan yang bermakna dengan obesitas $(p=0.013$ : $O R=4,2)$. Asupan energi yang lebih merupakan faktor risiko terjadinya obesitas $(p=0,032$ : $O R=3,2)$. Tidak terdapat hubungan antara aktivitas fisik dengan kejadian obesitas $(p=0,589$ : $O R=1,3)$.

Simpulan : Riwayat pemberian ASI tidak eksklusif berisiko 4,2 kali meningkatkan kejadian obesitas pada anak. Asupan energi tinggi berisiko 3,2 kali meningkatkan kejadian obesitas pada anak. Aktifitas fisik rendah berisiko 1,3 kali meningkatkan kejadian obesitas pada anak.
\end{abstract}

Kata Kunci: ASI eksklusif; asupan energi; aktivitas fisik; obesitas

\section{PENDAHULUAN}

Obesitas merupakan masalah kesehatan di seluruh dunia. Prevalensi overweight dan obesitas pada anak di dunia 6,7\% pada tahun 2010. Di Afrika prevalensi anak overweight dan obesitas sebesar 8,5\% sedangkan di Asia prevalensi anak overweight dan obesitas sebesar 4,9\% tetapi jumlah anak yang terpapar lebih tinggi daripada Afrika yaitu sebanyak 18 juta jiwa. ${ }^{1}$ Di Amerika, $66 \%$ dewasa mengalami overweight, $32 \%$ obesitas dan $17 \%$ anak dan remaja usia 2-19 tahun mengalami overweight. ${ }^{2}$ Prevalensi obesitas meningkat dari tahun ke tahun. Menurut Riskesdas, pada tahun 2007 prevalensi overweight dan obesitas pada anak $12,2 \%$ dan meningkat pada tahun 2010 menjadi $14,0 \%{ }^{3}$ Usia yang rentan terhadap kejadian obesitas adalah prapubertas. Namun, pada usia prasekolah kejadian obesitas cenderung meningkat. Prevalensi obesitas pada anak usia prasekolah di dunia sebesar 33\%. Anak di Asia dan Afrika termasuk Indonesia memiliki risiko 2,5-3,5 kali lebih besar untuk obesitas. ${ }^{4}$ 
Obesitas pada anak berisiko 1,8 kali menjadi obesitas pada masa dewasa. ${ }^{5}$ Obesitas pada anak berdampak pada penurunan prestasi belajar dan dampak psikososial seperti kurang percaya diri dan menarik diri dari sosial. ${ }^{6}$ Terdapat beberapa faktor yang berperan terhadap kejadian obesitas pada anak. Faktor tersebut antara lain keturunan/genetik; asupan makanan; aktifitas fisik; riwayat makan seperti pemberian ASI, berat badan lahir dan parental obesity.

Pemberian ASI eksklusif adalah tindakan memberikan ASI kepada bayi tanpa memberikan cairan atau makanan lain sejak lahir sampai usia 6 bulan. $^{7}$ WHO telah merekomendasikan pemberian ASI eksklusif selama 6 bulan dan dilanjutkan sampai usia 2 tahun. ASI merupakan makanan terbaik bagi bayi karena mengandung semua zat gizi yang dibutuhkan bayi dalam jumlah yang sesuai dan zat imunologik yang melindungi bayi dari infeksi. Pemberian ASI eksklusif selama 6 bulan dapat melindungi bayi dari berbagai penyakit termasuk gangguan lambung dan gangguan pernapasan. Hal ini disebabkan adanya antibodi yang terkandung dalam kolostrum ASI. Pemberian ASI juga dapat mencegah kejadian obesitas pada anak. Bayi yang diberi ASI dapat mengatur asupan energi berhubungan dengan respon internal dalam menyadari rasa kenyang. Kadar insulin dan hormon leptin lebih seimbang pada bayi yang diberikan ASI sehingga dapat mencegah obesitas. ${ }^{8}$

Beberapa penelitian menyebutkan pemberian ASI dapat menurunkan risiko terjadinya obesitas pada anak. Sebuah penelitian menyebutkan bahwa angka overweight tinggi pada anak usia 4 tahun yang tidak mendapat ASI atau hanya mendapat ASI kurang dari 1 bulan. ${ }^{8}$ Rasio odds kejadian obesitas dengan pemberian ASI selama 6-12 bulan dibandingkan dengan anak yang tidak mendapat ASI adalah 0,70. Pemberian ASI > 12 bulan dibandingkan dengan anak yang tidak mendapat ASI berisiko 0,49 kali untuk menjadi obesitas. Kejadian overweight semakin turun dengan bertambahnya durasi pemberian $\mathrm{ASI}^{8}{ }^{8} \mathrm{Pada}$ tahun 2005 sebuah penelitian di Jerman menyatakan bahwa terdapat hubungan yang kuat antara lama pemberian ASI dengan penurunan risiko obesitas pada anak. Setiap satu bulan pemberian ASI dapat menurunkan risiko obesitas sebesar 4\%. ${ }^{9}$ Pemberian ASI merupakan cara sederhana untuk mencegah terjadinya obesitas pada anak.

Pemberian ASI eksklusif di Indonesia masih rendah. Data Survei Demografi Kesehatan Indonesia tahun 2002 menunjukkan bahwa cakupan pemberian ASI eksklusif pada bayi di Indonesia sebesar 40\%, sedangkan pada tahun 2007 mengalami penurunan menjadi 32\%. Menurut riskesdas tahun 2010, bayi usia 5 bulan yang mendapat ASI eksklusif hanya sebesar $15,3 \%{ }^{3} \quad$ Berdasarkan hasil laporan Dinas Kesehatan Kota Semarang pada tahun 2011, pemberian ASI eksklusif di Semarang hanya $24,19 \%$. Hal ini berbanding terbalik dengan kejadian overweight dan obesitas pada anak yang dari tahun ke tahun mengalami peningkatan. ${ }^{3}$

Berdasarkan paparan di atas, peneliti tertarik ingin mengetahui apakah terdapat hubungan pemberian ASI eksklusif dengan kejadian obesitas pada anak usia 4-5 tahun.

\section{METODE PENELITIAN}

Penelitian ini dilakukan pada anak usia 4-5 tahun yang bersekolah TK di TK IT Bina Amal Semarang dan TK Negeri Semarang. Waktu pelaksanaan penelitian ini adalah 1 bulan, yaitu pada pertengahan bulan Agustus sampai September 2013. Penelitian ini termasuk ke dalam lingkup gizi masyarakat dengan desain case control. Pengambilan subjek penelitian dengan consecutive sampling berdasarkan ciri tertentu dari semua anggota populasi sampai jumlah subjek terpenuhi. Pengambilan sampel diawali dengan screening terhadap seluruh murid TK di TK IT Bina Amal Semarang dan TK Negeri Semarang meliputi berat badan dan tinggi badan. Jumlah subjek dalam penelitian ini adalah 56 anak yang terdiri dari 28 anak obesitas yang masuk dalam kelompok kasus dan 28 anak tidak obesitas yang masuk dalam kelompok kontrol.

Kriteria inklusi dari kelompok kasus adalah anak umur 4-5 tahun yang tercatat sebagai murid TK IT Bina Amal Semarang dan TK Negeri Semarang serta memiliki nilai Z-skor berdasarkan $\mathrm{IMT} / \mathrm{U} \geq 2 \mathrm{SD}$, sedangkan kriteria inklusi dari kelompok kontrol adalah anak umur 4-5 tahun yang tercatat sebagai murid TK IT Bina Amal Semarang dan TK Negeri Semarang serta memiliki nila Z-skor berdasarkan IMT/U $<2 \mathrm{SD}$. Kriteria eksklusi dalam penelitian ini adalah anak dalam keadaan sakit atau dalam perawatan dokter dan pindah sekolah ketika penelitian masih berlangsung.

Screening awal dilakukan pada semua murid TK di TK IT Bina Amal Semarang dan TK Negeri Semarang dengan menimbang berat badan menggunakan timbangan digital dengan ketelitian $0,1 \mathrm{~kg}$ dan mengukur tinggi badan menggunakan microtoise kapasitas $200 \mathrm{~cm}$ dengan ketelitian 0,1. 
Data berat badan dan tinggi badan anak digunakan untuk menghitung IMT dan menghitung nilai Zskor berdasarkan IMT/Umur. Hasil dari perhitungan nilai Z-skor akan didapatkan prevalensi obesitas pada anak di TK tersebut. Sebanyak 56 anak yang terpilih kemudian dilakukan pengambilan data yang meliputi data riwayat pemberian ASI eksklusif, data asupan energi menggunakan formulir FFQ (Food Frequency Questionaire), data aktivitas fisik menggunakan recall aktivitas fisik, data berat badan lahir, data parental obesity. Data riwayat pemberian ASI eksklusif pada penelitian ini diartikan sebagai riwayat pemberian ASI saja kepada bayi tanpa makanan atau minuman lain selama minimal 4 bulan. Data ini diperoleh melalui wawancara kepada orang tua menggunakan formulir kuesioner. Data asupan energi merupakan kebiasaan makan anak selama sebulan yang diperoleh menggunakan formulir FFQ kemudian dikonversikan ke dalam satuan kkal/hari yang dihitung menggunakan nutrisurvey. Asupan energi yang didapatkan kemudian dibandingkan dengan angka kecukupan gizi. Kategori asupan energi yaitu dikategorikan normal jika asupan energi 70$100 \%$ dan lebih apabila asupan energi $>100 \%{ }^{25}$ Data aktivitas fisik anak dilakukan dengan mencatat kegiatan anak selama 2 hari, yaitu hari biasa dan hari libur kemudian dirata-rata. Kategori untuk aktivitas fisik adalah dikatakan rendah jika tingkat aktivitas fisik $<$ 1,6 dan dikatakan sedang jika 1,6-1,89. ${ }^{26}$ Data berat badan lahir diperoleh melalui wawancara kepada orang tua. Kategori untuk berat badan lahir adalah normal jika berat badan lahir $\geq 2,5 \mathrm{~kg}$ dan rendah jika berat badan lahir $<2,5 \mathrm{~kg}^{3}$. Data parental obesity diperoleh dengan mengukur berat badan dan tinggi badan orang tua kemudian menghitung IMT. Dikategorikan obesitas jika IMT $\geq 25$ dan dikategorikan tidak obesitas jika IMT $<25$. $^{2}$ Anak dikatakan memiliki orang tua obesitas jika salah satu atau kedua orang tuanya obesitas.

Data yang dikumpulkan dalam penelitian ini adalah identitas subjek, berat badan, tinggi badan, riwayat pemberian ASI eksklusif, asupan energi, aktivitas fisik, berat badan lahir, parental obesity. Data yang telah diperoleh kemudian dianalisis dengan menggunakan program komputer. Analisis univariat dilakukan untuk mengidentifikasi data karakteristik subjek, seperti umur, asupan energi dan aktivitas fisik. Analisis bivariat dilakukan dengan uji Chi Square.

\section{HASIL PENELITIAN \\ Karakteristik Subjek Penelitian}

Skrining awal dilakukan dengan melibatkan 204 anak TK yang berasal dari 2 TK di Semarang dengan melakukan penimbangan berat badan dan pengukuran tinggi badan. Hasil dari skrining tersebut terdapat $20,58 \%$ anak obesitas. Karakteristik subjek dalam penelitian ini dapat dilihat pada tabel 1.

Tabel 1. Karakteristik subjek penelitian

\begin{tabular}{|c|c|c|c|c|c|c|}
\hline & \multicolumn{3}{|c|}{ Obesitas } & \multicolumn{3}{|c|}{ Tidak obesitas } \\
\hline & Min & maks & rerata $\pm S D$ & Min & maks & rerata \pm SD \\
\hline Usia (tahun) & 4,10 & 5,29 & $4,75 \pm 0,30$ & 4,00 & 5,61 & $4,87 \pm 0,44$ \\
\hline Berat Badan $(\mathrm{kg})$ & 19,60 & 50,80 & $26,94 \pm 6,67$ & 11,70 & 25,00 & $20,01 \pm 3,39$ \\
\hline Tinggi badan $(\mathrm{cm})$ & 100,10 & 130,50 & $111,282 \pm 7,45$ & 91,20 & 119,90 & $109,53 \pm 6,99$ \\
\hline Asupan Energi (kkal) & 1255,70 & 2176,60 & $\begin{array}{c}11694,34 \pm \\
257,24\end{array}$ & 1193,18 & 1686,20 & $\begin{array}{c}1478,01 \pm \\
119,18\end{array}$ \\
\hline $\begin{array}{l}\text { Pengeluaran energi } \\
\text { (kkal) }\end{array}$ & 624,00 & 2023,87 & $972,32 \pm 288,25$ & 488,06 & 1032,26 & $751,68 \pm 150,31$ \\
\hline $\begin{array}{l}\text { Tingkat aktivitas } \\
\text { fisik }\end{array}$ & 1,20 & 1,74 & $1,49 \pm 0,15$ & 1,24 & 1,89 & $1,56 \pm 0,19$ \\
\hline $\begin{array}{l}\text { Kecukupan asupan } \\
\text { energi }(\%)\end{array}$ & 81,01 & 140,43 & $109,31 \pm 16,59$ & 77,02 & 108,79 & $95,35 \pm 7,68$ \\
\hline
\end{tabular}

Berdasarkan tabel di atas menunjukkan bahwa rerata berat badan pada kelompok obesitas adalah $26,94 \mathrm{~kg}$ dan 20,01 $\mathrm{kg}$ pada kelompok tidak obesitas. Rerata asupan energi dan kecukupan energi pada kelompok obesitas lebih tinggi dibandingkan dengan kelompok tidak obesitas.
Rerata tingkat aktivitas fisik pada kelompok obesitas lebih rendah dibandingkan dengan kelompok tidak obesitas. 


\section{Hubungan Karakterisitik Subjek dengan Kejadian Obesitas}

Penentuan derajat obesitas pada anak menggunakan nilai Z-skor berdasarkan IMT/U yang kemudian dikategorikan menjadi obesitas dan tidak obesitas. Riwayat pemberian ASI eksklusif dinyatakan dalam kategori ASI eksklusif dan tidak ASI eksklusif. Riwayat pemberian ASI eksklusif lebih banyak pada kelompok tidak obesitas. Pada kelompok obesitas sebesar $78,6 \%$ tidak ASI eksklusif dan sebesar $21,4 \%$ mendapat ASI eksklusif. sedangkan pada kelompok tidak obesitas sebesar 53,6\% ASI eksklusif dan 46,4\% tidak ASI eksklusif. Berdasarkan hasil analisis menggunakan uji Chi square mendapatkan nilai $\mathrm{p}<0,05$ sehingga dapat disimpulkan bahwa terdapat hubungan bermakna antara riwayat pemberian ASI eksklusif dengan kejadian obesitas. Nilai OR (Odds Ratio) dapat diartikan bahwa anak yang tidak mendapatkan ASI eksklusif berisiko 4,23 kali lebih besar mengalami obesitas dibandingkan anak yang mendapatkan ASI eksklusif.

Terdapat faktor lain yang mempengaruhi terjadinya obesitas pada anak selain riwayat pemberian ASI eksklusif, yaitu asupan energi. Sebesar $67,9 \%$ anak pada kelompok obesitas memiliki asupan energi lebih. Hasil analisis menggunakan uji Chi square diperoleh nilai $\mathrm{p}<$ 0,05 sehingga dapat disimpulkan bahwa terdapat hubungan bermakna antara asupan energi dengan kejadian obesitas pada anak. Nilai OR yang diperoleh dapat diartikan bahwa anak dengan asupan energi lebih memiliki risiko obesitas 3,26 kali lebih besar dibandingkan dengan anak dengan asupan energi normal.
Aktivitas fisik merupakan faktor lain yang berpengaruh terhadap kejadian obesitas pada anak. Hasil analisis menggunakan uji Chi square diperoleh nilai $\mathrm{p}>0,05$ sehingga dapat disimpulkan bahwa tidak terdapat hubungan bermakna antara aktivitas fisik dengan kejadian obesitas pada anak. Berdasarkan nilai OR yang diperoleh dapat diartikan bahwa anak dengan aktivitas fisik ringan berisiko obesitas 1,33 kali lebih besar dibandingkan anak dengan aktivitas fisik sedang.

Hasil dari penelitian ini menunjukkan bahwa pada kedua kelompok obesitas dan kelompok tidak obesitas mempunyai berat badan lahir normal sebesar 94,6\%. Masing-masing kelompok hanya terdapat 1 subjek dengan berat badan lahir rendah. Berdasarkan hasil analisis menggunakan uji Chi square diperoleh nilai $\mathrm{p}>$ 0,05 sehingga dapat disimpulkan bahwa tidak terdapat hubungan bermakna antara berat badan lahir dengan kejadian obesitas pada anak. Nilai OR yang diperoleh sebesar 1 sehingga dapat diartikan bahwa berat badan lahir bukan merupakan faktor terjadinya obesitas pada anak.

Parental Obesity adalah obesitas pada orang tua yang dapat menjadi faktor risiko obesitas pada anak. Hasil dari penelitian menunjukkan bahwa pada kelompok obesitas sebesar $32,1 \%$ mempunyai orang tua yang obesitas dan $67,9 \%$ dengan orang tua tidak obesitas. Hasil analisis menggunakan uji Chi square diperoleh nilai $\mathrm{p}>0,05$ sehingga dapat disimpulkan bahwa tidak terdapat hubungan bermakna antara parental obesity dengan kejadian obesitas pada anak. Tabel silang karakteristik subjek dengan obesitas dapat dilihat pada tabel 2.

Tabel 2. Tabel silang karakteristik subjek dengan kejadian obesitas

\begin{tabular}{|c|c|c|c|c|c|c|}
\hline & & \multicolumn{2}{|c|}{ Status Gizi } & \multirow[b]{2}{*}{ Total } & \multirow[b]{2}{*}{$\begin{array}{c}P \\
\text { value }\end{array}$} & \multirow[b]{2}{*}{ OR } \\
\hline & & Obesitas & $\begin{array}{l}\text { Tidak } \\
\text { obesitas }\end{array}$ & & & \\
\hline \multirow{2}{*}{$\begin{array}{c}\text { Riwayat pemberian } \\
\text { ASI }\end{array}$} & $\begin{array}{ll}\text { Tidak } & \text { ASI } \\
\text { eksklusif } & \end{array}$ & $22(78,6 \%)$ & $13(46,4 \%)$ & $\begin{array}{l}35 \\
(62,5 \%)\end{array}$ & \multirow[b]{2}{*}{0,01} & \multirow[b]{2}{*}{4,23} \\
\hline & ASI eksklusif & $6(21,4 \%)$ & $15(53,6 \%)$ & $\begin{array}{l}21 \\
(37,5 \%)\end{array}$ & & \\
\hline \multirow[t]{2}{*}{ Asupan energi } & Lebih & $19(67,9 \%)$ & $11(39,3 \%)$ & $\begin{array}{l}30 \\
(53,6 \%)\end{array}$ & \multirow[t]{2}{*}{0,03} & \multirow[t]{2}{*}{3,26} \\
\hline & Normal & $9(32,1 \%)$ & $17(60,7 \%)$ & $\begin{array}{l}26 \\
(46,4 \%)\end{array}$ & & \\
\hline \multirow[t]{2}{*}{ Aktivitas fisik } & Ringan & $17(60,7 \%)$ & $15(53,6 \%)$ & $\begin{array}{l}32 \\
(57,1 \%)\end{array}$ & \multirow[t]{2}{*}{0,58} & \multirow[t]{2}{*}{1,33} \\
\hline & Sedang & $11(39,3 \%)$ & $13(46,4 \%)$ & $\begin{array}{l}24 \\
(42,9 \%)\end{array}$ & & \\
\hline Berat badan lahir & Rendah & $1(3,6 \%)$ & $1(3,6 \%)$ & $2(3,6 \%)$ & 1,00 & 1,00 \\
\hline
\end{tabular}




\begin{tabular}{lllllll}
\hline & Normal & $27(96,4 \%)$ & $27(96,4 \%)$ & 54 & & \\
parental obesity & Obesitas & $9(32,1 \%)$ & $13(46,4 \%)$ & $\begin{array}{l}\text { 22 } \\
(39,4 \%)\end{array}$ & 0,27 & 0,54 \\
& Tidak obesitas & $19(67,9 \%)$ & $15(53,6 \%)$ & $34,3 \%)$ & & \\
& & & & $(60,7 \%)$ & & \\
\hline
\end{tabular}

Hasil dari stratifikasi diperoleh nilai OR untuk asupan energi sebesar 3,17 . Nilai $\mathrm{OR}_{\text {stratifikasi }}$ tersebut dibandingkan dengan $\mathrm{OR}_{\mathrm{M}-\mathrm{H}} \quad 4,23$ memiliki perbedaan $23,6 \%$ sehingga asupan energi bukan sebagai efek perancu. Perbedaan nilai $\mathrm{COR}_{\text {lebih }}$ (2) dan $\mathrm{COR}_{\text {normal }}(4,8)$ cukup jauh sehingga asupan energi sebagai efek modifikasi. Hal ini dapat diartikan bahwa asupan energi bukan merupakan efek perancu tetapi sebagai efek modifikasi. Nilai $\mathrm{OR}_{\text {stratifikasi }}$ untuk aktivitas fisik adalah 3,81. Nilai $\mathrm{OR}_{\text {stratifikasi }}$ tersebut dibandingkan dengan nilai $\mathrm{OR}_{\mathrm{M}-\mathrm{H}}$ memiliki perbedaan $23,6 \%$ sehingga aktivitas fisik bukan sebagai efek perancu. Perbedaan nilai $\mathrm{COR}_{\text {ringan }}$ dan $\mathrm{COR}_{\text {sedang }}$ cukup jauh sehingga aktivitas fisik sebagai efek modifikasi. Hal ini dapat diartikan bahwa aktivitas fisik bukan merupakan efek perancu tetapi sebagai efek modifikasi. Nilai $\mathrm{OR}_{\text {stratifikasi }}$ untuk parental obesity adalah 4,48. Nilai $\mathrm{OR}_{\text {stratifikasi }}$ tersebut dibandingkan dengan nilai $\mathrm{OR}_{\mathrm{M}-\mathrm{H}}$ memiliki perbedaan $23,6 \%$ sehingga parental obesity bukan sebagai efek perancu. Perbedaan nilai $\mathrm{COR}_{\text {obesitas }}$ dan $\mathrm{COR}_{\text {non-obesitas }}$ cukup jauh sehingga parental obesity sebagai efek modifikasi. Hal ini dapat diartikan bahwa parental obesity bukan merupakan efek perancu tetapi sebagai efek modifikasi. Data ini dapat dilihat pada tabel 3 .

Tabel 3. Tabel asupan energi, aktivitas fisik, parental obesity dan riwayat ASI eksklusif dengan kejadian obesitas

\begin{tabular}{|c|c|c|c|c|c|c|c|}
\hline & & \multirow{2}{*}{\multicolumn{2}{|c|}{$\begin{array}{c}\text { Riwayat pemberian } \\
\text { ASI }\end{array}$}} & \multicolumn{2}{|c|}{ Status gizi } & \multirow[b]{2}{*}{ COR } & \multirow[b]{2}{*}{ OR } \\
\hline & & & & Obesitas & $\begin{array}{l}\text { Tidak } \\
\text { obesitas }\end{array}$ & & \\
\hline \multirow[t]{5}{*}{ Asupan energi } & Lebih & $\begin{array}{l}\text { Tidak } \\
\text { eksklusif }\end{array}$ & ASI & $\begin{array}{l}16 \\
(84,2 \%)\end{array}$ & $8(72,7 \%)$ & \multirow{3}{*}{4,8} & \multirow{5}{*}{3,17} \\
\hline & & ASI eksklusif & & $3(15,8 \%)$ & $3(27,3 \%)$ & & \\
\hline & & Tidak & ASI & $6(66,7 \%)$ & $5(29,4 \%)$ & & \\
\hline & Normal & eksklusif & & & & \multirow[t]{2}{*}{2} & \\
\hline & & ASI eksklusif & & $3(33,3 \%)$ & $12(70,6 \%)$ & & \\
\hline \multirow[t]{4}{*}{ Aktivitas fisik } & Ringan & Tidak & ASI & 12 & $9(60 \%)$ & \multirow{2}{*}{1,6} & \multirow{4}{*}{3,81} \\
\hline & Millgall & ASI eksklusif & & $5(29,4 \%)$ & $6(40 \%)$ & & \\
\hline & & Tidak & ASI & 10 & $4(30,8 \%)$ & \multirow[b]{2}{*}{22,5} & \\
\hline & Sedang & $\begin{array}{l}\text { eksklusif } \\
\text { ASI eksklusif }\end{array}$ & & $(90,9 \%)$ & $9(6920 \%$ & & \\
\hline \multirow{3}{*}{$\begin{array}{c}\text { Parental } \\
\text { obesity }\end{array}$} & Ohesitas & Tidak & ASI & $8(88,9 \%)$ & $6(46,2 \%)$ & \multirow{2}{*}{9,3} & \multirow{3}{*}{4,48} \\
\hline & & ASI eksklusif & & $1(11,1 \%)$ & $7(53,8 \%)$ & & \\
\hline & $\begin{array}{c}\text { Tidak } \\
\text { obesitas }\end{array}$ & $\begin{array}{l}\text { Tidak } \\
\text { eksklusif } \\
\text { ASI eksklusif }\end{array}$ & ASI & $\begin{array}{l}14 \\
(73,7 \%) \\
5(26,3 \%)\end{array}$ & $7(46,7 \%)$ & 3,2 & \\
\hline
\end{tabular}

\section{PEMBAHASAN}

Hasil penelitian ini menunjukkan bahwa dari 56 subjek hanya $37,5 \%$ yang ketika bayi diberikan ASI eksklusif. Sebanyak $65,7 \%$ ibu tidak memberikan ASI eksklusif dengan alasan ASI tidak dapat memenuhi kebutuhan bayi karena bayi masih sering menangis jika hanya diberikan ASI. Penambahan susu formula dianggap dapat mencukupi kebutuhan bayi sehingga bayi tenang dan tidak menangis. Selain itu, sebanyak 34,2\% ibu juga menjelaskan bahwa ketika bayi lahir langsung diberikan susu formula oleh bidan atau pihak rumah sakit dengan alasan ASI ibu belum keluar. Hal ini terjadi karena kurangnya informasi bahwa memberikan susu formula terutama pada hari-hari pertama kelahiran dapat mengganggu 
produksi ASI dan menghambat kesuksesan menyusui di kemudian hari. Bayi yang diberikan susu formula akan cepat kenyang dan cenderung malas untuk menyusu sehingga dapat menyebabkan produksi ASI menurun. Bayi yang menangis tetap disusui ASI karena hisapan dari bayi dapat meningkatkan dan melancarkan produksi ASI. Walau hanya diberikan ASI dapat memenuhi semua kebutuhan bayi. Bayi yang menangis belum tentu karena kurang ASI. Tanda bayi cukup ASI diantaranya jumlah buang air kecil minimal 6 kali dalam sehari, buang air besar 2-5 kali sehari, bayi cukup tidur dan akan bangun ketika lapar. ${ }^{23,24}$

Sebuah penelitian di Jerman menyebutkan bahwa pemberian ASI selama 6 bulan lebih signifikan dalam mencegah risiko obesitas dibandingkan dengan pemberian ASI selama 3 bulan. ${ }^{13}$ Beberapa penelitian lain juga menyebutkan bahwa lama pemberian ASI dapat mempengaruhi terjadinya obesitas pada anak. ${ }^{8,9}$ Hasil penelitian ini menunjukkan bahwa terdapat hubungan yang bermakna antara riwayat pemberian ASI eksklusif dengan kejadian obesitas $(p=0,013)$. Hasil ini sejalan dengan penelitian di Jerman menyebutkan bahwa durasi pemberian ASI dapat mencegah terjadinya obesitas pada anak. ${ }^{13}$ Nilai OR hasil dari penelitian ini dapat diinterpretasikan bahwa anak yang ketika bayi tidak mendapat ASI eksklusif berisiko obesitas 4,23 kali lebih besar dibandingkan dengan anak yang mendapat ASI eksklusif.

Pemberian ASI eksklusif dapat mencegah obesitas pada anak dengan beberapa mekanisme biologis. Bayi yang diberikan ASI dapat mengatur jumlah susu yang dikonsumsi. Kemampuan mengatur asupan energi berhubungan dengan kemampuan menghisap dan respons internal dalam menyadari rasa kenyang. Kandungan susu formula yang padat energi dapat merangsang sistem endokrin untuk mengeluarkan lebih banyak insulin dan growth factor sehingga meningkatkan kadar lemak tubuh. Kadar insulin pada bayi yang diberi susu formula lebih tinggi dan memiliki respon insulin lebih panjang daripada bayi yang diberi ASI. Hal ini menstimulasi deposisi jaringan lemak yang berakibat bertambahnya berat badan, obesitas, dan risiko diabetes melitus tipe 2 pada masa dewasa. Bayi yang diberi ASI memiliki konsentrasi hormon leptin lebih seimbang daripada bayi yang diberi susu formula. Leptin berperan dalam mengatur keseimbangan energi melalui pengaturan selera makan. Jika terdapat energi tersimpan yang berlimpah, dihasilkan leptin dalam jumlah besar. Leptin bekerja dengan cara mengahmbat jalur anabolisme dan memicu jalur katabolisme. Hasil akhir dari leptin adalah mengurangi asupan makanan dan meningkatkan pengeluaran energi. Jika leptin dalam tubuh tidak seimbang, keseimbangan energi tidak tercapai dan dapat terjadi obesitas.

Faktor lain yang dapat menjadi faktor risiko obesitas adalah asupan energi. Sebuah jurnal Athena menyebutkan bahwa asupan energi berhubungan dengan obesitas pada anak dan remaja. ${ }^{14}$ Hasil dari penelitian ini menunjukkan bahwa terdapat hubungan yang bermakna antara asupan energi dengan kejadian obesitas pada anak $(p=0,032)$. Hal ini sejalan dengan penelitian di Amerika yang menyebutkan bahwa peningkatan asupan energi berhubungan dengan peningkatan risiko terjadinya obesitas. ${ }^{15}$ Nilai OR yang diperoleh dari penelitian ini diinterpretasikan bahwa anak dengan asupan energi berlebih memiliki risiko obesitas 3,26 kali lebih besar daripada anak dengan asupan energi normal. Pada penelitian ini jenis makanan penyumbang energi terbesar adalah makanan jajanan dan makanan cepat saji. Asupan energi yang berlebih dapat meningkatkan simpanan lemak dalam tubuh sehingga dapat memicu terjadinya obesitas. Obesitas bisa terjadi apabila asupan energi tidak seimbang dengan keluaran energi. ${ }^{16}$

Aktivitas fisik juga merupakan faktor risiko terjadinya obesitas. Obesitas dapat terjadi apabila terdapat ketidakseimbangan antara asupan energi dan aktivitas fisik. ${ }^{15}$ Sebuah penelitian di Amerika yang menyebutkan bahwa terdapat hubungan antara aktivitas fisik dan asupan energi dengan obesitas. Aktivitas fisik yang rendah dan asupan energi berlebih dapat meningkatkan terjadinya obesitas. ${ }^{17}$ Hasil dari penelitian ini menyebutkan bahwa tidak terdapat hubungan yang bermakna antara aktivitas fisik dan kejadian obesitas pada anak. Hasil tersebut sejalan dengan suatu penelitian tahun 2006 yang menyebutkan bahwa tidak terdapat hubungan antara aktivitas fisik dengan obesitas. Hal ini disebabkan pengambilan data aktivitas fisik anak hanya dalam 2 hari sehingga kurang dapat menggambarkan aktivitas fisik anak secara umum. Pada penelitian ini anak yang memiliki pengeluaran energi yang tinggi adalah anak yang banyak bermain di luar rumah seperti sepakbola dan bersepeda. Peningkatan aktivitas fisik dan diet rendah kalori merupakan strategi penurunan berat badan dan mencegah obesitas. Seseorang yang kurang melakukan aktivitas fisik menyebabkan tubuh kurang 
menggunakan energi yang tersimpan dalam tubuh. Oleh karena itu, apabila asupan energi berlebihan tanpa diimbangi dengan aktivitas fisik yang sesuai dapat menyebabkan obesitas. ${ }^{25}$

Berat badan lahir dapat menjadi faktor risiko terjadinya obesitas pada anak. Bayi dengan berat badan lahir berlebih berisiko obesitas di kemudian hari. Sedangkan bayi yang ketika di dalam kadungan kurang gizi, membutuhkan gizi lebih ketika di luar kadungan. Hal ini menyebabkan bayi tumbuh dengan mengatur tubuhnya untuk menyimpan lemak banyak dan mengeluarkannya dengan efisien sehingga memicu terjadinya obesitas. Sebuah penelitian di Jerman menyatakan bahwa berat badan lahir berlebih dan berat badan lahir rendah dapat meningkatkan risiko obesitas pada anak. ${ }^{19}$ Namun, hasil dari penelitian ini menunjukkan $\mathrm{p}>0,05$, sehingga dapat diartikan tidak terdapat hubungan bermakna antara berat badan lahir dengan obesitas pada anak. Hal ini sejalan dengan penelitian di Finlandia yang menyatakan bahwa tidak terdapat hubungan antara berat badan lahir dengan tingkat BMI pada anak. ${ }^{20}$ Bayi dengan berat badan lahir berlebih atau rendah apabila pola makan dan aktivitas fisik seimbang dapat tumbuh menjadi anak dengan berat badan normal.

Parental obesity merupakan salah satu faktor terjadinya obesitas pada anak. Kecenderungan obesitas terjadi pada anak yang memiliki orang tua obesitas. Hal ini dibuktikan dengan hasil penelitian di Spanyol yang menyebutkan bahwa terdapat hubungan yang bermakna antara obesitas pada orang tua dengan obesitas anak. ${ }^{21}$ Faktor genetik berperan dalam menentukan jumlah unsur lemak dalam lemak yang berukuran besar dan banyak yang akan diturunkan pada bayi selama dalam kandungan. Hal ini yang menyebabkan memungkinkan anak menjadi obesitas. Namun dengan pola makan dan aktivitas fisik yang seimbang dapat mencegah terjadinya obesitas. Hasil dari penelitian ini menunjukkan bahwa tidak terdapat hubungan yang bermakna antara obesitas pada orang tua dengan kejadian obesitas pada anak. Hal ini sejalan dengan penelitian di Finlandia yang menyebutkan bahwa obesitas pada orang tua bukan merupakan faktor obesitas pada anak. ${ }^{20}$

Pada suatu penelitian, variabel dianggap sebagai efek modifikasi apabila terdapat perbedaan cukup jauh antara $\mathrm{COR}_{(+)}$dan $\mathrm{COR}_{(-)}$dan dianggap sebagai efek perancu apabila perbedaan antara $\mathrm{OR}_{\text {stratifikasi }}$ dan $\mathrm{OR}_{\mathrm{M}-\mathrm{H}}>25 \%$. Efek perancu adalah jenis variabel yang berhubungan dengan variabel bebas dan variabel terikat tetapi bukan merupakan variabel antara. Efek modifikasi terjadi apabila hubungan antar variabel ditentukan oleh variabel ketiga (effect modifier). ${ }^{27}$ Pada penelitian ini asupan energi, aktivitas fisik dan parental obesity bukan merupakan efek perancu tetapi sebagai efek modifikasi.

\section{SIMPULAN}

1. Riwayat pemberian ASI eksklusif memiliki hubungan bermakna dengan kejadian obesitas pada anak usia 4-5 tahun. Besar risiko riwayat pemberian ASI tidak eksklusif 4,23 kali dalam menyebabkan obesitas pada anak usia 4-5 tahun.

2. Asupan energi memiliki hubungan bermakna dengan kejadian obesitas pada anak usia 4-5 tahun. Besar risiko asupan energi berlebih 3,26 kali dalam menyebabkan obesitas pada anak usia 4-5 tahun.

3. Aktivitas fisik tidak memiliki hubungan bermakna dengan kejadian obesitas pada anak usia 4-5 tahun. Besar risiko aktivitas fisik 1,33 kali dalam menyebabkan obesitas pada anak usia 4-5 tahun.

4. Berat badan lahir tidak memiliki hubungan bermakna dengan kejadian obesitas pada anak usia 4-5 tahun.

5. Parental obesity tidak memiliki hubungan bermakna dengan kejadian obesitas pada anak usia 4-5 tahun.

\section{SARAN}

Ibu sebaiknya memberikan ASI eksklusif kepada bayinya untuk mencegah terjadinya obesitas pada masa anak-anak. Asupan energi dan aktivitas fisik anak juga harus seimbang untuk mencapai status gizi yang optimal.

\section{DAFTAR PUSTAKA}

1. De Onis M., Blössner M., Borghi E. Global Prevalence and Trends of Overweight and Obesity among Preschool Children. American Journal of Clinical Nutrition. 2010;92:1257-64.

2. Gee Molly. Weight Imbalance : Obesity and Overweight. In : L. Katheleen M, Sylvia ES. Krause's Food, Nutrition, and Diet Therapy, $12^{\text {nd }}$ Edition. USA : Saunders. 2008.21:538

3. Kementrian Kesehatan. Riset Kesehatan Dasar (Riskesdas). Kemenkes RI; Jakarta. 2010.

4. De Onis M., Blössner M. Prevalence and Trends of Overweight Among Preschool Children in Developing Countries. American Journal of Clinical Nutrition. 2000;72:1032-9. 
5. Loke K. Y. Consequences of Cildhood and Adolescent Obesity. Asia Pasific Journal Clinical Nutrition. 11(3): S702-S704. 2002.

6. WHO. Obesity: Preventing and Managing The Global Epidemic. World Health Organization (Geneva); 2000.

7. WHO. The World Health Organization's Infant Feeding Recommendation. World Health Organization.

8. M. Laurence, Strawn G., Mei Zuguo. Does Breastfeeding Protect Against Pediatric Overweight? Analysis of Longitudinal Data From the Center for Disease Control an Prevention Pediatric Nutrition Surveillance System. American Academy of Pediatrics. 2004;113; e81.

9. Harder Thomas, Bergmann R., Kallischnigg G., Plagemann A., Duration of Breastfeeding and Risk of Overweight: A Meta-Analysis. American Journal of Epidemiology. 2005;162:397-403.

10. Betran AP, Onis M, Lauer JA, Villar J. Ecological study of effect of breast feeding on infant mortality in Latin America. Amerika Latin dan Karibia: $\mathrm{Br}$ Med J; 323:1-5; 2001.

11. Adriani M dan Wirjatmadi B. Peranan Gizi Dalam Siklus Kehidupan. Jakarta: Kencana Perdana Media Group; 2012.

12. Josefa KG. F. Faktor-Faktor yang Mempengaruhi Perilaku Pemberian ASI Eksklusif pada Ibu. [skipsi]. 2011. Available from : http://eprints.undip.ac.id.

13. Weyermann M., Rothenbacher D., Brenner H. Duration of Breastfeeding and Risk of Overweight in Childhood: A Prospective Birth Cohort Study from Germany. International Journal of Obesity. 2006;30:1281-1287.

14. Kosti Rena I., Panagiotakos B Demosthenes. The Epidemic of Obesity in Children and Adolescents in The World. Cent Eur J Publ Health. 2006; 14(4):151-159.

15. Troiano Richard P., Briefel Ronette R., Carnoll Margaret D., Bialostosky Karil. Energy and fat intakes of children and adolescents in the United States: data from the National Health and Nutrition Examination Surveys1-3. American Journal of Clinical Nutrition. 2000; 72(suppl):1343S-53S.

16. McGloin AF., Livingstone MBE., Greene LC., Webb SE., Gibson JMA., Jebb SA., et al. Energy and fat intake in obese and lean children at varying risk of obesity. International Journal of Obesity. 2002;26,200-207.

17. Crespo Carlos J., Smit Ellen, Troiano Richard P., Bartlett Susan J., Macera Caroline A., Andersen Ross E. Television watching energy intake and obesity in US children. Arch Pediatr Adolsc Med. 2001;155:360-365.

18. Reilly John J., Kelly Louise, Montgomery Colette, Williamson A., Fisher A., McColl John H., et al. Physical activity to prevent obesity in young children: cluster randomised controlled trial. BMJ. 2006.
19. Apfelbacher CJ., Loerbroks A., Cairns J., Behrendt H., Ring J., Kramer Ursula. Predictors of overweight and obesity in five to seven-year-old children in Germany: Results from cross-sectional studies. BMC Public Health. 2008;8:171.

20. Fuentes RM, Notkola IL, Shemeikka S, Tuomilehto J, Nissinen A:Tracking of body mass index during childhood: a 15-year pro-spective population-based family study in eastern Finland. Int $\mathrm{J}$ Obes Relat Metab Disord 2003, 27(6):716-721

21. Moreno LA., Tomas C, Gonzalez-Gross M., Bueno G., Perez-Gonzalez JM., Bueno M. Microenvironmental and socio-demographic determinants of childhood obesity. Int J Obes Relat Metab Disord. 2004;28(suppl 3):S16-20.

22. Predictor Factor for Childhood Obesity in a Spanish Case Control Study. Elsevier Inc. Journal of Nutrition. 2007;379-384.

23. Suradi R., Hegar B., Partiwi I Gusti AN., Marzuki A Nanis S., Ananta Y. Indonesia Menyusui. Ikatan Dokter Anak Indonesia. Jakarta. 2010.

24. Gibney Michael J., Margetts Barrie M., Kearney John M., Arab L. Gizi Kesehatan Mayarakat (Public Health Nutrition). Penerbit Buku Kedokteran. Jakarta:ECG,2008.

25. Wiesmann Doris, Bassett Lucy, Benson Todd, Hoddinott John. Validation of the World Food Programme's Food Consumption Score and Alternative Indicators of Household Food Security. International Food Policy Research Institute. 2009.

26. Csizmadi Ilona, Lo Siou G., Friedenreich C. M., Owen N., Robson P. J. Hours Spent and Energy Expended in Physical Activity Domains: Result from The Tomorrow Project Cohort in Alberta, Canada. International Jurnal of Behavioral Nutrition and Physical Activity. 2011.

27. Sastroasmoro Sudigdo, Ismael Sofyan. Dasar Dasar Metodologi Penelitian Klinis. Edisi 2. Jakarta: Sagung Seto, 2002. 